\title{
Polymorphisms Related to Bovine Leptin Gene and Association with Productive and Reproductive Traits in Nellore Heifers
}

\author{
J. S. Fernandes ${ }^{a}$, B. A. Crispim ${ }^{a}$, L. O. Seno ${ }^{b}$, R. R. Aspilcueta-Borquis ${ }^{c}$, \& A. Barufatti ${ }^{a, *}$ \\ ${ }^{a}$ Faculty of Biological and Environmental Sciences, Federal University of Grande Dourados

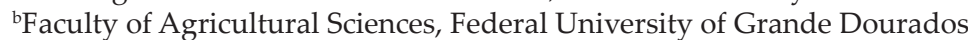 \\ 'Faculty of Agricultural and Veterinary Sciences, São Paulo State University \\ Federal University of Grande Dourados, Dourados/Itahum Highway, Km. 12, Zip Code 79804-970, Dourados, Mato \\ Grosso do Sul, Brazil \\ *Corresponding author: barufattialexeia@gmail.com \\ (Received 16-09-2019; Revised 30-10-2019; Accepted 18-11-2019)
}

\begin{abstract}
The identification of genes and polymorphisms in female zebu related to the leptin gene that may be involved in better productive and reproductive performances is relevant to the livestock and economic sector. Thus, the objective of this study was to evaluate the SNP markers (T954M and C305T) and the BM1500 microsatellite and to analyze their associations with the traits of body weight, age at first calving (AFC), calving interval (CI), and reproductive efficiency (RE) in Nellore heifers. DNA extraction was performed, followed by the amplification of all markers. Association analyses were carried out with each marker and each traits separately. The result showed that no significant association was found between the reproductive traits and all markers and between body weight and both SNP markers. For the BM1500 microsatellite, the effect of the allele 138 ( $p=0.0383$ ) on body weight was observed, with the growth curve for this allele being related to the lower asymptotic weight. Therefore, the BM1500 microsatellite marker was the only one with a significant association with a productive trait providing information about the condition of body weight in Nellore heifers.
\end{abstract}

Keywords: body weight; growth curve; zebu cattle

\section{INTRODUCTION}

In Zebu cattle, traits related to female sexual precocity are economically important, because they provide the larger disponibility of animals in the herds which leads to a greater profitability for the production sector (Santana et al., 2012). Traits such as age at first calving (AFC) and calving interval (CI) are parameters used in evaluation of reproductive efficiency (RE) of females bovine (Lacerda et al., 2018). The onset of reproductive activity is indicated by puberty which is dependent of several factors such as race, environmental, food availability, and body weight. Regarding body weight, females of zebu cattle tend to reach the maturity of their reproductive system when the body weight is around half of the adult weight (Estill, 2014).

Puberty occurs when body energy stores are in adequate conditions and the signaling to the brain indicating such sufficient energy is provided by leptin (Wylie, 2011). Leptin is a peptide hormone produced primarily by adipocytes that play a role in body condition (Kowalski et al., 2014). Polymorphisms related to the leptin gene (LEP) and its receptor (LEPR) have been associated with several traits of economic relevance in the livestock sector (Buchanan et al., 2002; Komisarek \& Dorynek, 2006; Ferraz et al., 2009; Oliveira et al., 2013; Silva et al., 2014).
The leptin gene is directly and indirectly associated with the productive and reproductive traits, so it is relevant to investigate molecular markers that can seek for associations with economically important traits. Therefore, the aim of this study was to evaluate two single nucleotide polymorphism (SNP) markers, T945M e C305T, located in the leptin gene and in the leptin receptor gene, respectively, and the BM1500 microsatellite marker, located near to the stop codon of the leptin gene, then seek for the associations with AFC, CI, RE, and body weight traits in Nellore heifers.

\section{MATERIALS AND METHODS}

\section{Animals and Phenotypes}

Phenotype data from the Nellore heifers (Bos taurus indicus) used in this study were obtained from a commercial herd from São Jorge de Maracay Farm (Iguatemi/MS, Brazil). A total of 138 heifers, born between 1996 and 2007, were maintained exclusively with pasture (Brachiaria spp.) and mineral supplementation.

The live weight from birth up to 48 months of age was evaluated considering the several measurements obtained, characterizing a set of repeated measurements or longitudinal data. We also analyzed reproductive traits such as the age at first calving (AFC), calving in- 
terval (CI), and reproductive efficiency (RE). The RE was calculated referring to Wilcox (1957) as follows:

$$
\operatorname{RE}(\%)=\left(365^{*}(\mathrm{~N}-1)^{*} 100\right) / \mathrm{D}
$$

where RE (\%) is the reproductive efficiency; $\mathrm{N}$ is the total number of parturitions; $\mathrm{D}$ is the number of days from the first to the last parturition; and 365 is the interval (days) between parturition desired.

\section{DNA Extraction and Genotyping}

DNA extraction was performed using aliquots of $300 \mu \mathrm{L}$ of blood samples following the methodology described by Crispim et al. (2012). DNA quality and concentration were determined using DS-11 spectrophotometer $\left(\right.$ DeNovix $\left.^{\circledR}\right)$.

The DNA samples were genotyped for the following markers: SNP T945M (Komisarek \& Dorynek, 2006), SNP C305T (Buchanan et al., 2002) and BM1500 microsatellite (Fitzsimmons et al., 1998). Polymerase chain reaction amplifications and enzymatic reactions were performed in a thermal cycler BIORAD ${ }^{\circledR}$, model MyCycler ${ }^{\mathrm{TM}}$ Thermal Cycler.

The forward (5'GCAACTACAGATGCTCTAC TTTTGT3') and reverse (5'CAGGGAAATTTCCCTCAA GTTCAA3') primers were used to amplify a $400 \mathrm{bp}$ fragment of the SNP T945M, based on sequences of the bovine leptin receptor gene available in GenBank (AN: AJ580801.1). The amplification reaction contained $6 \mu \mathrm{L}$ of ultra-pure water, $1.5 \mu \mathrm{L}(10 \mathrm{pM} / \mu \mathrm{L})$ of each primer, $13 \mu \mathrm{L}$ of the PCR Master MIX (ThermoScientific ${ }^{\circledR}$, USA), and $2 \mu \mathrm{L}$ of the genomic DNA $(50 \mathrm{ng} / \mu \mathrm{L})$. The amplification protocol consisted of initial denaturation $\left(94^{\circ} \mathrm{C}\right.$ for 5 $\mathrm{min}$ ), followed by 35 cycles (denaturation at $94^{\circ} \mathrm{C}$ for 30 $\mathrm{s}$, annealing at $56^{\circ} \mathrm{C}$ for $30 \mathrm{~s}$, and extension at $72^{\circ} \mathrm{C}$ for 40 s) and final extension at $72^{\circ} \mathrm{C}$ for $4 \mathrm{~min}$. The fragments were digested in reaction containing $5 \mu \mathrm{L}$ of ultra-pure water, $1 \mu \mathrm{L}$ of $10 \mathrm{X}$ buffer, $3 \mu \mathrm{L}$ of restriction enzyme TaqI (ThermoScientific $\left.{ }^{\circledR}, \mathrm{USA}\right)$, and $5 \mu \mathrm{L}$ of PCR product at $65^{\circ} \mathrm{C}$ for $4 \mathrm{~h}$.

The forward (5'ATGCGCTGTGGACCCCTGTA TC3') and reverse (5'TTCCGGAAGGTCCAGAGATG ACACCA3') primers were used to amplify a fragment of $94 \mathrm{bp}$ of the SNP C305T, based on sequences of the bovine leptin genes available in GenBank (AN: AY138588.1). The amplification reaction contained $6 \mu \mathrm{L}$ of ultra-pure water, $2.0 \mu \mathrm{L}(10 \mathrm{pM} / \mu \mathrm{L})$ of each primer, $12.5 \mu \mathrm{L}$ of the PCR Master MIX (ThermoScientific ${ }^{\circledR}$, USA), and $2.5 \mu \mathrm{L}(50 \mathrm{ng} / \mu \mathrm{L})$ of genomic DNA. The amplification conditions consisted of initial denaturation $\left(94^{\circ} \mathrm{C}\right.$ for $\left.4 \mathrm{~min}\right)$ followed by 35 cycles (denaturation at $94^{\circ} \mathrm{C}$ for $45 \mathrm{~s}$, annealing at $56^{\circ} \mathrm{C}$ for $55 \mathrm{~s}$, and extension at $72^{\circ} \mathrm{C}$ for $50 \mathrm{~s}$ ) and final extension at $72^{\circ} \mathrm{C}$ for $5 \mathrm{~min}$. The fragments were digested in reaction containing $13 \mu \mathrm{L}$ of ultra-pure water, $1.5 \mu \mathrm{L}$ of the buffer, $2 \mu \mathrm{L}$ of restriction enzyme Kpn2I (ThermoScientific ${ }^{\circledR}, \mathrm{USA}$ ), and $12 \mu \mathrm{L}$ of the amplified product at $37^{\circ} \mathrm{C}$ for $6 \mathrm{~h}$.

Finally, the forward (5'GATGCAGCAGACCAAG TGG3') and reverse (CCCTTGCTAGAACCCAGG3') primers were used to amplify the BM1500 microsatellite available in GenBank (AN: G18568.1). The amplification reaction contained $7.5 \mu \mathrm{L}$ of ultra-pure water, 1.5 $\mu \mathrm{L}(10 \mathrm{pM} / \mu \mathrm{L})$ of each primer, $12.5 \mu \mathrm{L}$ of the PCR Mix (ThermoScientific ${ }^{\circledR}$, USA), and $2.0 \mu \mathrm{L}(50 \mu \mathrm{g} / \mu \mathrm{L})$ of the genomic DNA. The amplification conditions showed an initial denaturation step $\left(94^{\circ} \mathrm{C}\right.$ for $\left.3 \mathrm{~min}\right)$, followed by 25 cycles (denaturation at $94^{\circ} \mathrm{C}$ for $45 \mathrm{~s}$, annealing at $57^{\circ} \mathrm{C}$ for $30 \mathrm{~s}$, and extension at $72^{\circ} \mathrm{C}$ for $45 \mathrm{~s}$ ); and final extension at $72^{\circ} \mathrm{C}$ for $4 \mathrm{~min}$.

The fragments obtained from the enzymatic digestion for both SNP were analyzed in $2 \%$ agarose gel electrophoresis stained with ethidium bromide $(0.05 \mu \mathrm{g} /$ $\mathrm{mL}$ ), and the alleles for the BM1500 microsatellite were submitted to $7 \%$ polyacrylamide gel electrophoresis stained with silver nitrate.

\section{Populations and Statistical Analyses}

The population parameters examined (allele and genotype frequencies, expected $\left(\mathrm{H}_{\mathrm{E}}\right)$ and observed $\left(\mathrm{H}_{\mathrm{O}}\right)$ heterozygosity, polymorphic information content (PIC), and Hardy-Weinberg equilibrium (HWE) test were calculated using the CERVUS v.3.0 software (Kalinowski et al., 2007).

The statistical analyses were performed using the SAS $^{\circledR}$ (Statistical Analysis System) University Edition software (available online). The association analyses between the reproductive traits (AFC, $\mathrm{CI}$, and $\mathrm{RE}$ ) and the molecular markers considered as fixed effects of the year of birth of the cow and each genotype of the molecular markers individually (SNP T945M and C305T and BM1500 microsatellite), as well as the random effect of sire, using the mixed model in the PROC MIXED procedure.

In the association analyses between the markers and the repeated measures of weight were considered as fixed effects of the year of birth of the cow, the age of the animal at the weighing date, the genotypes of each marker individually (both SNP), and the random effect of sire nested to each animal.

The association analysis for the BM1500 microsatellite was performed considering the absence and presence of the alleles in each genotype ( 0 for absence and 1,2 , and 3 for presence, respectively, for the alleles 138, 147, and 149). Numbers of copies of each allele were also evaluated in both the homozygous and heterozygous forms $(0,1$, and 2 copies) and the absence and presence of the alleles in homozygosis ( 0 and 1 , respectively).

The fixed and random effects for the BM1500 microsatellite were the same used for the SNP markers. The PROC MIXED procedure from SAS ${ }^{\circledR}$ software was used to analyze the mixed model, considering the age of the animal at the weighing date as a repeated measure in the REPEATED function. The TOEP (Toeplitz) variance structure was the most adequate for the data set analyzed.

The non-linear Gompertz model (Laird, 1965) was applied in the analysis with the weight data and the BM1500 microsatellite in order to obtain the growth curve parameters using the Marquardt method (Marquardt, 1963). The nonlinear regression by the NLIN procedure of the SAS ${ }^{\circledR}$ software was used to get the fit to the reduced model (average curve) and the complete model (curve fit for each allele separately). The 
Gompertz model was calculated as follows:

$$
\mathrm{y}_{\mathrm{t}}=\mathrm{C}^{(-\mathrm{b}(-\mathrm{at})}+\varepsilon_{\mathrm{t}}
$$

where $y$ represents the average weight of the animals as a function of age $(t) ; C$ is the asymptotic or adult weight, when $\mathrm{t} \rightarrow \infty ; b$ is an integration constant without biological interpretation with the role of modeling the growth curve to a sigmoidal format, from birth to adulthood of the animal; $a$ is the rate or maturity index, which measures the variation in the speed of growth, being an indicator of the speed in which the animal reaches the asymptotic weight; and $\varepsilon$ is the random error associated with each weighing (Silva et al., 2011; Marinho et al., 2013). After obtaining the curves for both models, the Lack of Fit test was performed to test the fit of the complete model in relation to the reduced model.

\section{RESULTS}

\section{Population Analyses}

The SNP T945M presented two allelic variations (C and $T$ alleles) and three fragment sizes, $400 \mathrm{bp}$ resulting from amplification (TT genotype) and 375 and $25 \mathrm{bp}$ (CC genotype), obtained after the enzymatic digestion using the restriction endonuclease TaqI. The heterozygous CT genotype showed three different fragment sizes: 400, 375, and $25 \mathrm{bp}$. The $\mathrm{C}$ allele was the most frequent, along with the CC genotype, found in $73 \%$ of the population (Table 1 ).

Two allelic variations were also observed for the SNP C305T and the sizes of the fragments obtained after amplification and enzymatic digestion with Kpn2I endonuclease were $94 \mathrm{bp}$ (TT genotype) and 75 and $19 \mathrm{bp}$ (CC genotype), respectively. The heterozygous CT genotype showed the three fragment sizes and was found in $29 \%$ of the population.

Three alleles and five genotypes were obtained for the BM1500 microsatellite. The allele 147 was the most frequent $(73 \%)$, as well as the CC genotype, present in $55 \%$ of the population (Table 1 ). The lowest allele frequency was observed for the 138 allele $(6 \%)$ and any homozygous genotype was observed for this allele.
The PIC values ranged from 0.22 (SNP T945M) to 0.37 (BM1500 microsatellite) and the Hardy-Weinberg Equilibrium test was not significant for any marker.

\section{Association Analyses}

No significant association was observed between all the markers and the reproductive traits (Table 2). The analysis of the mixed model between both SNP markers and the weight data showed that no significant effect for T945M ( $p=0.1641)$ and C305T $(p=0.0681)$ was observed. On the other hand, in the evaluation of BM1500 microsatellite and the weight data, a significant association was found for the allele $138(\mathrm{p}=0.0383)$. The parameters of the Gompertz model obtained by the fit of the nonlinear model of the weight-age data related to the alleles of the BM1500 microsatellite were presented in Table 3.

The comparison of fit of growth curves of the completed and reduced model by the Lack of Fit test presented significant effect $(p=0.0128)$, therefore a significant difference was observed for the fit of the curves of both models (Figure 1). The Figure 1 showed the growth curves for the completed and reduced model for the weight-age data of Nellore heifers in relation to the alleles obtained for the BM1500 microsatellite marker. The curve for allele 138 showed the lowest growth for weight during the 48 months of observation and the Lack of Fit test was significant, meaning that the curve for the allele 138 was also significant, so this allele was associated with the lower weight in the heifers.

\section{DISCUSSION}

The highest allele frequency (85\%) for T945M was observed for the C allele (Table 1). Silva et al. (2012) and Pinto et al. (2011) reported in their study with Nellore bulls a similar frequency for the same allele i.e., $88 \%$ and $89 \%$ respectively. The genotype frequencies for the CC genotype were higher in both studies.

For the C305T, there was a predominance of the C allele (82\%) over the $\mathrm{T}$ allele $(0.18)$ and higher frequency for the CC genotype (0.67), results that are similar with the study of Oliveira et al. (2013) that used animals from

Table 1. Number of individuals $(\mathrm{N})$, allelic and genotypic frequencies, expected $\left(\mathrm{H}_{\mathrm{E}}\right)$ and observed heterozygosity $\left(\mathrm{H}_{\mathrm{O}}\right)$, polymorphic information content (PIC) and Hardy-Weinberg Equilibrium (HWE) for a population of Nellore heifers

\begin{tabular}{|c|c|c|c|c|c|c|c|}
\hline Marker & $\mathrm{N}$ & Allele frequency & Genotypic frequency & $\mathrm{H}_{\mathrm{O}}$ & $\mathrm{H}_{\mathrm{E}}$ & PIC & HWE \\
\hline \multirow{3}{*}{ T945M } & 101 & \multirow{3}{*}{$\begin{array}{l}\mathrm{C}=0.85 \\
\mathrm{~T}=0.15\end{array}$} & $\mathrm{CC}=0.73$ & \multirow{3}{*}{0.24} & \multirow{3}{*}{0.25} & \multirow{3}{*}{0.22} & \multirow{3}{*}{ NS } \\
\hline & 34 & & $\mathrm{CT}=0.24$ & & & & \\
\hline & 3 & & $\mathrm{TT}=0.02$ & & & & \\
\hline \multirow{3}{*}{ C305T } & 93 & \multirow{3}{*}{$\begin{array}{l}\mathrm{C}=0.82 \\
\mathrm{~T}=0.18\end{array}$} & $C C=0.67$ & \multirow{3}{*}{0.29} & \multirow{3}{*}{0.29} & \multirow{3}{*}{0.25} & \multirow{3}{*}{ NS } \\
\hline & 41 & & $\mathrm{CT}=0.29$ & & & & \\
\hline & 4 & & $\mathrm{TT}=0.03$ & & & & \\
\hline \multirow{6}{*}{ BM1500 } & 0 & & $138 / 138=0.00$ & \multirow{6}{*}{0.4} & \multirow{6}{*}{0.41} & \multirow{6}{*}{0.37} & \multirow{6}{*}{ NS } \\
\hline & 12 & & $147 / 138=0.08$ & & & & \\
\hline & 76 & $138=0.06$ & $149 / 138=0.02$ & & & & \\
\hline & 3 & $\begin{array}{l}147=0.73 \\
149=021\end{array}$ & $147 / 147=0.55$ & & & & \\
\hline & 40 & & $149 / 147=0.30$ & & & & \\
\hline & 7 & & $149 / 149=0.05$ & & & & \\
\hline
\end{tabular}

Note: NS= not significant. 
Table 2. Estimated average and standard deviations for the of age at first calving (AFC), calving interval (CI) and reproductive efficiency (RE) for the genotypes of the SNP T945M and C305T and for the alleles of the BM1500 microsatellite in a population of Nellore heifers

\begin{tabular}{|c|c|c|c|c|}
\hline Marker & Genotype/ Allele & AFC & CI & RE \\
\hline \multirow[t]{4}{*}{ T945M } & $\mathrm{CC}$ & $29.81 \pm 0.64$ & $420.05 \pm 10.61$ & $84.88 \pm 2.77$ \\
\hline & CT & $30.84 \pm 0.87$ & $427.11 \pm 15.32$ & $85.88 \pm 3.66$ \\
\hline & $\mathrm{TT}$ & $29.57 \pm 2.14$ & $435.93 \pm 41.32$ & $76.25 \pm 8.35$ \\
\hline & $\mathrm{p}$ value & 0.3244 & 0.8162 & 0.5122 \\
\hline \multirow[t]{4}{*}{ С $305 \mathrm{~T}$} & CC & $29.85 \pm 0.69$ & $424.81 \pm 11.34$ & $85.06 \pm 2.91$ \\
\hline & $\mathrm{CT}$ & $30.04 \pm 0.76$ & $415.40 \pm 12.76$ & $84.51 \pm 3.20$ \\
\hline & $\mathrm{TT}$ & $30.22 \pm 1.84$ & $437.60 \pm 28.51$ & $87.13 \pm 7.21$ \\
\hline & $\mathrm{p}$ value & 0.9446 & 0.6143 & 0.9251 \\
\hline \multicolumn{5}{|l|}{ BM1500* } \\
\hline \multirow[t]{3}{*}{ Allele 138} & 0 & $28.35 \pm 3.64$ & $447.20 \pm 60.10$ & $78.23 \pm 15.55$ \\
\hline & 1 & $28.07 \pm 4.12$ & $473.73 \pm 68.79$ & $77.75 \pm 13.09$ \\
\hline & $\mathrm{p}$ value & 0.9518 & 0.4279 & 0.2034 \\
\hline \multirow[t]{3}{*}{ Allele 147} & 0 & $28.18 \pm 3.19$ & $448.96 \pm 60.76$ & $82.57 \pm 10.52$ \\
\hline & 2 & $28.33 \pm 3.72$ & $449.81 \pm 61.48$ & $77.83 \pm 15.56$ \\
\hline & $\mathrm{p}$ value & 0.4539 & 0.3369 & 0.1607 \\
\hline \multirow[t]{3}{*}{ Allele 149} & 0 & $28.18 \pm 3.79$ & $448.78 \pm 59.10$ & $77.53 \pm 15.81$ \\
\hline & 3 & $28.56 \pm 3.49$ & $451.26 \pm 65.02$ & $79.33 \pm 14.35$ \\
\hline & $\mathrm{p}$ value & 0.749 & 0.8203 & 0.4983 \\
\hline \multirow[t]{3}{*}{ Allele copy $138^{*}$} & 0 & $28.35 \pm 3.64$ & $447.20 \pm 60.10$ & $78.23 \pm 15.55$ \\
\hline & 1 & $28.07 \pm 4.12$ & $473.73 \pm 68.79$ & $77.75 \pm 13.09$ \\
\hline & $\mathrm{p}$ value & 0.9518 & 0.4279 & 0.2034 \\
\hline \multirow[t]{4}{*}{ Allele copy 147} & 0 & $28.18 \pm 3.18$ & $448.96 \pm 60.76$ & $82.57 \pm 10.52$ \\
\hline & 1 & $28.54 \pm 3.81$ & $458.47 \pm 69.72$ & $78.06 \pm 14.89$ \\
\hline & 2 & $28.18 \pm 3.68$ & $444.28 \pm 55.52$ & $77.68 \pm 16.09$ \\
\hline & $\mathrm{p}$ value & 0.7552 & 0.1945 & 0.3112 \\
\hline \multirow[t]{4}{*}{ Allele copy 149} & 0 & $28.18 \pm 3.80$ & $448.78 \pm 59.10$ & $77.53 \pm 15.81$ \\
\hline & 1 & $28.60 \pm 3.49$ & $451.38 \pm 64.69$ & $78.77 \pm 14.70$ \\
\hline & 2 & $28.35 \pm 3.81$ & $450.68 \pm 71.83$ & $82.67 \pm 12.42$ \\
\hline & $\mathrm{p}$ value & 0.8412 & 0.8776 & 0.6196 \\
\hline \multirow[t]{3}{*}{ Allele 147 vs 147} & 0 & $28.48 \pm 3.69$ & $456.44 \pm 67.39$ & $78.81 \pm 14.28$ \\
\hline & 1 & $28.18 \pm 3.68$ & $444.28 \pm 55.52$ & $77.68 \pm 16.09$ \\
\hline & $\mathrm{p}$ value & 0.8358 & 0.2953 & 0.2972 \\
\hline \multirow[t]{3}{*}{ Allele 149 vs 149} & 0 & $28.32 \pm 3.68$ & $449.66 \pm 60.71$ & $77.93 \pm 15.41$ \\
\hline & 1 & $28.34 \pm 3.81$ & $450.68 \pm 71.83$ & $82.67 \pm 12.42$ \\
\hline & $p$ value & 0.57 & 0.7232 & 0.3784 \\
\hline
\end{tabular}

Note: *The copy of the allele 138 appears only in heterozygosity, so the average values obtained for the reproductive traits are the same for the 138 allele, as there is only one copy.

Obs.: The association analyses for the BM1500 microsatellite was performed using its alleles, so 0 is the absence of the allele and 1, 2 and 3 is the presence for the alleles 138, 147 and 149, respectively. The numbers of copies of each allele are 1 and 2 for homozygote and heterozygote genotype, respectively.

Table 3. Asymptotic weight $(C)$, integration constant $(b)$ and maturation rate $(a)$ and their standard deviations for the Gompertz model adjusted for weight-age data, from birth to 48 months age in Nellore heifers

\begin{tabular}{lccc}
\hline & \multicolumn{3}{c}{ Parameters } \\
\cline { 2 - 4 } & $C$ & $b$ & $a$ \\
\hline Average Curve (reduced model) & $436.8 \pm 3.85$ & $2.9342 \pm 0.07$ & $0.2807 \pm 0.007$ \\
Allele curve for alleles 147 and 149 & $443.0 \pm 4.14$ & $2.9003 \pm 0.07$ & $0.2720 \pm 0.007$ \\
Allele curve for allele 138 & $386.8 \pm 9.34$ & $3.4349 \pm 0.34$ & $0.3798 \pm 0.029$ \\
\hline
\end{tabular}

a commercial herd of Nellore cattle. Buchanan et al. (2002) found frequencies of 0.54 and 0.46 for the $C$ and $\mathrm{T}$ alleles, respectively, in a study performed with taurine breed and these authors also found a higher frequency for the C allele.

Fitzsimmons et al. (1998) studied the BM1500 mic- 


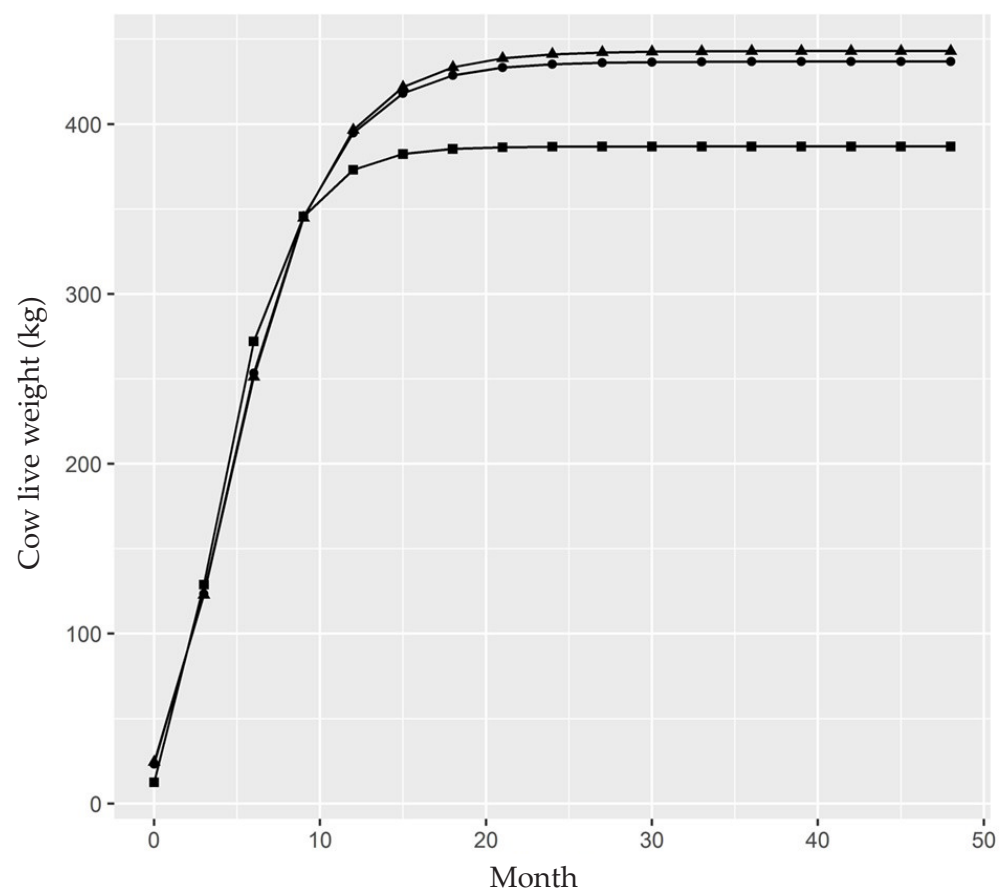

Figure 1. Growth curve of reduced model (BM1500 microsatellite marker) and growth curves of completed model (allele 138 and other alleles - 147 e 149) for weight measurement, from birth up to 48 months old, in Nellore heifers. $(\bullet=$ reduced model; $\boldsymbol{\Delta}=$ other alleles; $\boldsymbol{\bullet}=$ allele 138$)$.

rosatellite in taurine breed and observed a higher allele frequency for the 138 allele $(47 \%)$. This result differs from the present study where the 138 allele showed the lowest frequency (Table 1) and the genotype 138/138 was not observed. Silva et al. (2014) studied this marker in Nellore males and also found a lower frequency for the 138 allele $(8 \%)$, but the higher genotype frequency was observed for genotype 149/149 (70\%), differently from this study that found a higher frequency genotype to $147 / 147(55 \%)$.

The differences observed for the allelic and genotypic frequencies when compared with previous studies for the same markers are relevant, once studies in the literature were developed mostly with taurine bull.

The classification of Botstein et al. (1980) for PIC considers three categories, low (PIC $<0.25)$, moderate $(0.25<$ PIC $<0.50)$, and high (PIC $>0.50)$ informative. Both SNP markers presented low to moderate values of PIC and the BM1500 microsatellite presented a moderate informative PIC value. Despite being a marker with a high degree of polymorphic information, the PIC observed (0.37) may be justified by the size of the sample group.

The herd presented a non-significant result for the Hardy-Weinberg equilibrium test for all markers. The farm used the traits as selection indices based on the Nellore Brazil Program from the National Association of Researchers and Breeders (ANPC) and among the traits, several of them was related to body weight. Although the selection has been occurred in the herd for over 30 years, the frequencies observed for the markers were not influenced, therefore there were no deviations in the Hardy-Weinberg equilibrium.

Regarding the association analyses, both SNP markers and the BM1500 microsatellite had no influence on reproductive traits (Table 2). The body weight also showed no correlation with both SNP markers, however the BM1500 microsatellite presented a significant effect of the allele 138. This allele was associated with a lower weight in heifers and as observed in Figure 1, the curve for the allele 138 was lower when compared to the curve for the other alleles, in relation to the average asymptotic weight. It was observed that around the tenth month of the growth curves showed different behavior so the performance of the heifers was affected by the environment conditions and was not directly influenced by the maternal effects (Boligon et al., 2019).

These results corroborate with the population analysis (Table 1), where the frequencies found for the allele 138 were lower than the other ones and the genotype frequency for this allele was null. This fact indicates that during the selection process applied in this herd, the heifers with lower body weight were being eliminated because they did not present economic interest related to body weight. As a consequence, the allele was also eliminated because it was related to the lower body weight in females.

The microsatellite marker BM1500 is located approximately $3.6 \mathrm{~Kb}$ downstream of the leptin gene stop codon on bovine chromosome 4 (Buchanan et al., 2002). This condition has been associated with different fat triats in beef bulls (Fitzsimmons et al., 1998), body weight in Velásquez breed (Montoya et al., 2009), and carcass traits (Silva et al., 2014).

Leptin is a hormone mainly produced by white adipose tissue and is responsible for giving information to the brain about the body's fat store (Wylie, 2011), because the increase of body weight triggers the increase of adipose tissue, so more adipocytes induces the release 
of more leptin in the bloodstream that is detected by brain receptors (Catunda et al., 2014). The major role of the leptin in bovines is related to the onset of puberty that only occurs in adequate conditions of body energy store. Therefore, leptin displays an important role in reproduction because the maturity of reproductive system is dependent of puberty (Wylie, 2011; Symonds et al., 2016).

The reproductive parameters used in this research are puberty dependent because the maturity of reproductive system only occurs after puberty (Wylie, 2011). The population of bovine heifers analyzed comes from a commercial herd where the selection was based on reproductive phenotypes, so the results found for AFC, $\mathrm{CI}$, and RE reflect several years of selection applied in the animals, not being found significant association of these traits with the markers.

Despite the association with a trait that is not interesting from an economic point of view, the BM1500 marker may be used in marker assisted selection processes along with the other markers that also has significant associations with productive traits in beef cattle, in order to contribute to the better efficiency of the herd.

\section{CONCLUSION}

Both SNP markers did not have associations with the traits evaluated. The allele 138 for the BM1500 microsatellite was associated with lower body weight in Nellore heifers and it could be used as a genetic marker related to body weight.

\section{CONFLICT OF INTEREST}

The authors declare there is no conflict of interest with any financial, personal, or other relationships with other people or organization related to the material discussed in the manuscript.

\section{ACKNOWLEDGEMENT}

We thank National Council for the Improvement of Higher Education (CAPES), Brazilian National Council for Scientific and Technological Development (CNPq), Foundation for the Development of Education, Science and Technology of the State of Mato Grosso do Sul (FUNDECT) and Federal University of Grande Dourados (UFGD) for the financial support.

\section{REFERENCES}

Boligon, A. A., I. S. Vicente, V. M. Roso \& F. R. P. Souza. 2019. Direct and maternal annual genetic changes for selected traits. Acta Sci. Anim. Sci. 41: e42572. https://doi. org/10.4025/actascianimsci.v41i1.42572

Botstein, D., R. L. White, M. Skolnick, \& R. W. Davis. 1980. Construction of a genetic linkage map in man using restriction fragment length polymorphisms. Am. J. Hum. Genet. 32: 314-331.

Buchanan, F. C., C. J. Fitzsimmons, A. G. Van Kessel, T. D. Thue, D.C. Winkelman-Sim, \& S. M. Schmutz. 2002. Association of a missense mutation in the bovine leptin gene with carcass fat content and leptin mRNA levels. Genet. Sel. Evol. 34:105-116. https://doi. org/10.1186/1297-9686-34-1-105

Catunda, A.G.V., F.R.G. Lima, I.C.S. Lima, A.A.C. Machado, C.R.F. Gadelha, E.S. Pereira, G.A. Martins, \& A.C.N. Campos. 2014. O papel da leptina na reprodução dos ruminantes. Rev. Bras. Reprod. Anim. 38: 3-9.

Crispim, B. A., B. D. S. Silva, A. C. Banari, L. O, Seno, \& A. B .Grisolia. 2012. Allelic discrimination in naturalized ovine from Pantanal Sul-Matogrossense. J. Selva Andin. Res. Soc. 3: 3-13

Estill, C. T. 2014. Initiation of Puberty in Heifers. In Richard M. Hopper (ed.) Bovine Reproduction. John Wiley \& Sons, Inc. https://doi.org/10.1002/9781118833971.ch22

Ferraz, J. B. S., L. F. B. Pinto, F. V. Meirelles, J. P. Eler, F. M. Rezende, E. C. M. Oliveira, H. B. Almeida, B. Woodward \& D. Nkrumah. 2009. Association of single nucleotide polymorphisms with carcass traits in Nellore cattle. Genet. Mol. Res. 8: 1360-1366. https://doi.org/10.4238/ vol8-4gmr650

Fitzsimmons, C. J., S. M. Schmutz, R. D. Bergen \& J. J. McKinnon. 1998. A potential association between the BM 1500 microsatellite and fat deposition in beef cattle. Mamm Genome. 9: 432-434. https://doi.org/10.1007/s003359900791

Kalinowski, S. T., M. L. Taper \& T. C. Marshall. 2007. Revising how the computer program CERVUS accommodates genotyping error increases success in paternity assignment. Mol. Ecol. 16: 1099-1106. https://doi. org/10.1111/j.1365-294X.2007.03089.x

Komisarek, J. \& Z. Dorynek. 2006. The relationship between the T945M single nucleotide polymorphism in the leptin receptor gene (LEPR) and milk production traits in Jersey cows. Anim. Sci. Pap. Reports. 24: 271-277.

Kowalski, L. H., J. A. Freitas, S. R. Fernandes, P. R. Junior, J. I. Fernandes \& M. G. Silva. 2014. Leptina e grelina na produção de ruminantes. Rev. Ciências Agrárias. 37: 375-383.

Laird, A.K. 1965. Dynamics of relative growth. Growth, 29: 249-263.

Lacerda, V. V., G. S. Campos, V. M. Roso, F. R. P. Souza, C. C. Brauner \& A. A. Boligon. 2018. Effect of mature size and body condition of Nelore females on the reproductive performance. Theriogenology 118: 27-33. https://doi. org/10.1016/j.theriogenology.2018.05.036

Marinho, K. N. S., A. R. Freitas, A. J. S. Falcão, F. E. F. Dias. 2013. Nonlinear models for fitting growth curves of Nellore cows reared in the Amazon Biome. R. Bras. Zootec. 42: 645650. https://doi.org/10.1590/S1516-35982013000900006

Marquardt, D. W. 1963. An algorithm for least-squares estimation of nonlinear parameters. J. Soc. Indust. Appl. Math. 11: 431-441. https://doi.org/10.1137/0111030

Montoya A. E., M. F. Cerón-Muñoz, T. B. Esperanza, E. J. Ramirez \& P. A. Angel. 2009. Frecuencia de los marcadores del gen leptina en razas bovinas criollas y colombianas: I. Romosinuano, Chino Santandereano, Sanmartinero y Velásquez. Rev. Cient. 19: 38-48.

Oliveira, J. A., C. M. Cunha, B. A. Crispim, L. O. Seno, A. R. M. Fernandes, G. P. Nogueira \& A. B. Grisolia. 2013. Association of the leptin gene with carcass characteristics in Nellore cattle. Anim. Biotechnol. 24: 229-242. https://doi. org/10.1080/10495398.2013.770008

Pinto, L. F. B., J. B. S. Ferraz, V. B. Pedrosa, J. P. Eler, F. V. Meirelles, M. N. Bonin, F. M. Rezende, M. E. Carvalho, D. C. Cucco \& R. C. G. Silva. 2011. Single nucleotide polymorphisms in CAPN and leptin genes associated with meat color and tenderness in Nellore cattle. Genet. Mol. Res. 10: 2057-2064. https://doi.org/10.4238/vol10-3gmr1263

Santana, M. L., J. P. Eler, J. B. S. Ferraz \& E. C. Mattos. 2012. Genetic relationship between growth and reproductive 
traits in Nellore cattle. Animal 6: 565-570. https:/doi. org/10.1017/S1751731111001856

Silva, D. B.S., B. A. Crispim, L. E. Silva, J. A. Oliveira, F. Siqueira, L. O. Seno, \& A. B. Grisolia. 2014. Genetic variations in the leptin gene associated with growth and carcass traits in Nellore cattle. Genet. Mol. Res. 13: 3002-3012. https://doi.org/10.4238/2014.April.16.9

Silva, F. L., M. M. Alencar, A. R. Freitas, I. U. Packer \& G. B. Mourão. 2011. Curvas de crescimento em vacas de corte de diferentes tipos biológicos. Pesqui. Agropecu. Bras. 46: 262-271. https://doi.org/10.1590/S0100-204X2011000300006

Silva, R. C., J. B. Ferraz, F. V. Meirelles, J. P. Eler, J. C. Balieiro, D. C. Cucco, E. C. Mattos, F. M. Rezende, \& S. L. Silva. 2012. Association of single nucleotide polymorphisms in the bovine leptin and leptin receptor genes with growth and ultrasound carcass traits in Nellore cattle. Genet. Mol. Res. 11: 3721-3728. https://doi.org/10.4238/2012. August.17.10
Symonds, M. E., N. Dellschaft, M. Pope, M. Birtwistle, R. Alagal, D. Keisler, H. Budge. 2016. Developmental programming, adiposity, and reproduction in ruminants. Theriogenology 86: 120-129. https://doi.org/10.1016/j. theriogenology.2016.04.023

Wilcox, C. J., K. O. Pfau \& J. W. Bartlett. 1957. An investigation of the inheritance of female reproductive performance and longevity, and their interrelationships within a Holstein-Friesian herd. J. Dairy Sci. 40: 942-947. https:// doi.org/10.3168/jds.S0022-0302(57)94578-2

Wylie, A. R.G. 2011. leptin in farm animals: where are we and where can we go? Animal 5: 246-267. https://doi. org/10.1017/S1751731110001540 